\title{
Hepatic portal venous gas complicating Bickerstaff's encephalitis with Guillain Barré overlap
}

\section{Corinna Slawinski, ${ }^{1}$ Ed Parkin, ${ }^{2}$ Patrick Casey, ${ }^{1}$ Stephen Pettit ${ }^{2}$}

${ }^{1}$ Department of General Surgery, Blackpool Teaching Hospitals NHS Trust, Blackpool, UK

${ }^{2}$ Department of Surgery, Blackpool Fylde and Wyre NHS, Blackpool, UK

\section{Correspondence to}

Stephen Pettit,

stephenhpettit@btinternet.com

Accepted 20 July 2015
CrossMark

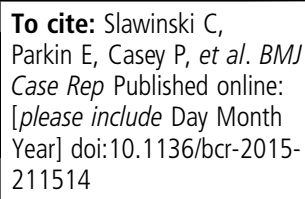

\section{DESCRIPTION}

Hepatic portal venous gas (HPVG) is a radiological finding often associated with intestinal ischaemia and high mortality. ${ }^{1}$ We report a 34 -year-old male patient who developed flaccid paralysis of all four limbs, areflexia and ophthalmoplegia after a short viral illness. A diagnosis of Bickerstaff's encephalitis with Guillain Barré overlap was made. ${ }^{2} \mathrm{He}$ was

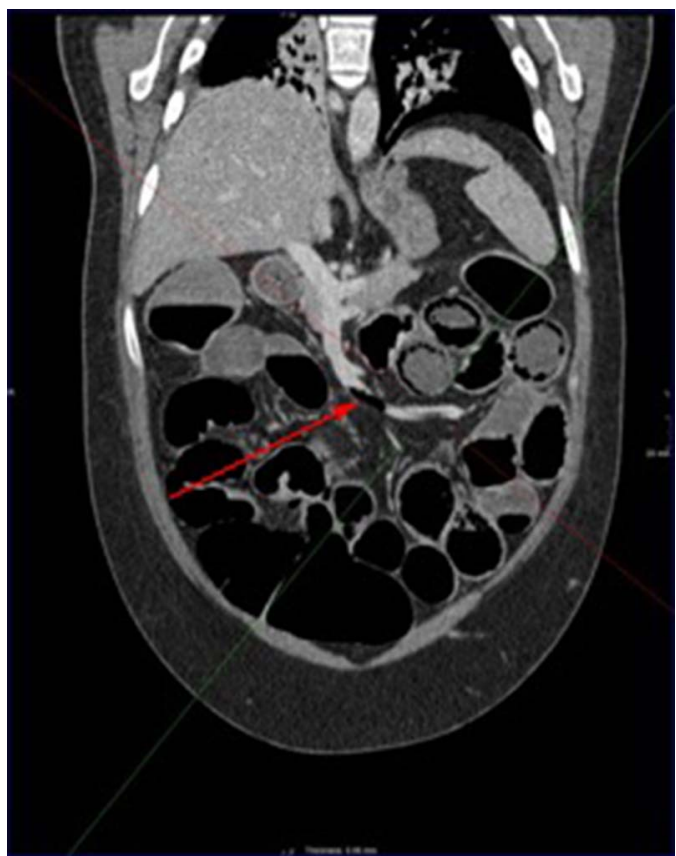

Figure 1 CT showing gas in the superior mesenteric vein (red arrow).

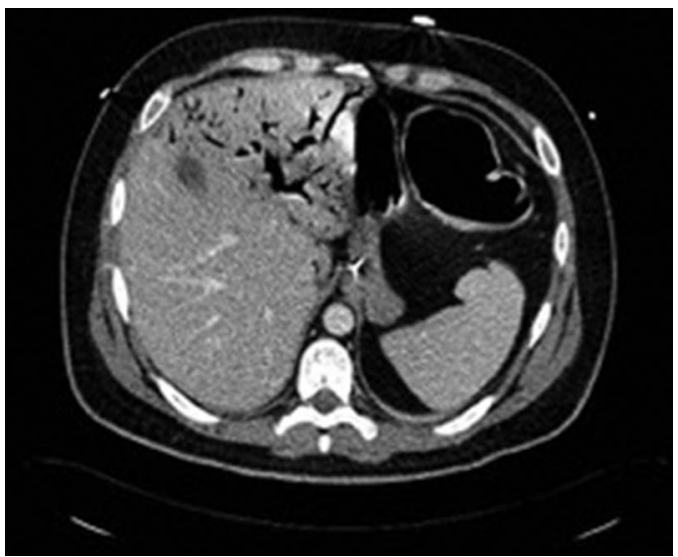

Figure 2 CT showing hepatic portal venous gas in the liver. ventilated, treated with immunoglobulins and received enteral nutrition via a nasogastric tube. Some neurological improvement was noted on day 22 in intensive care. On day 23 he developed marked abdominal distention with large volume faeculant nasogastric aspirates. CT showed marked dilation of his large and small bowel, intramural and mesenteric gas in his proximal jejunum, gas in his

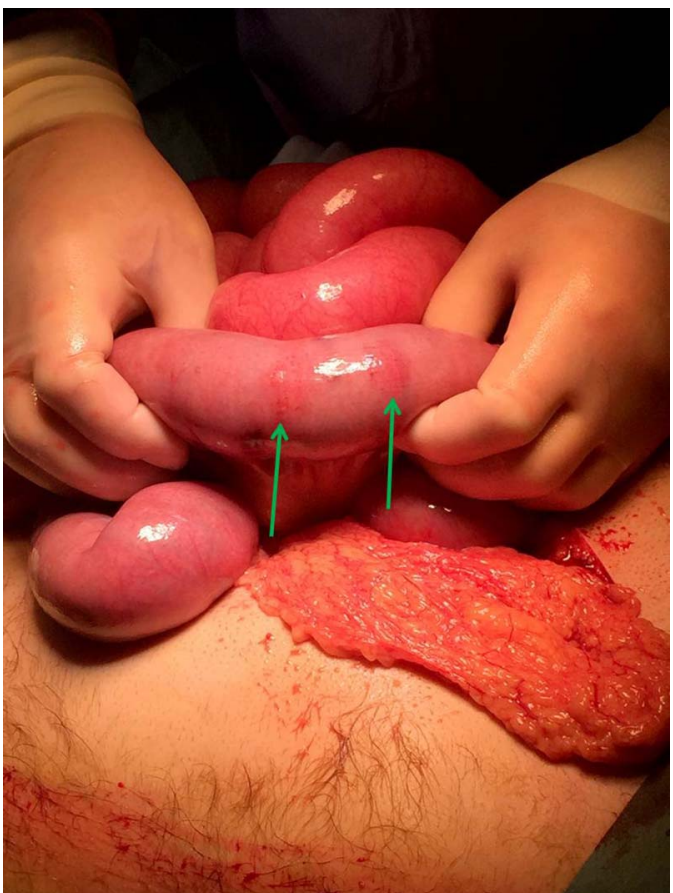

Figure 3 Operative photograph showing patchy ischaemia of dilated proximal jejunum (green arrows).

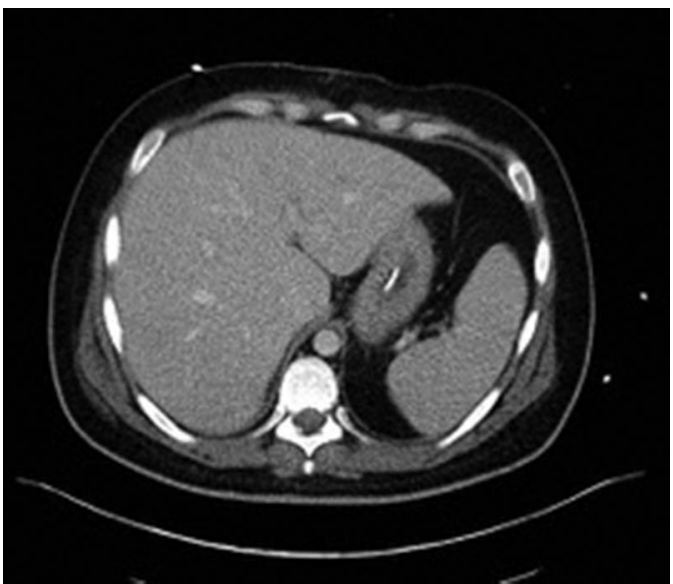

Figure 4 CT showing resolution of HPVG 6 days postlaparotomy. HPVG, hepatic portal venous gas. 
superior mesenteric vein (figure 1), and HPVG (figure 2). At laparotomy gross distention of the large and small bowel was present with breaches of the caecal serosa suggesting imminent perforation. Fifty centimetres of proximal jejunum had a patchy ischaemic appearance, but remained viable (figure 3). A caecostomy was used to decompress both large and small bowel following which the colour of the proximal jujunum returned to normal. A caecostomy tube was inserted and broad spectrum

\section{Learning points}

- Hepatic portal venous gas is an ominous radiological finding often caused by ischaemic small bowel where there is a high mortality.

- Small bowel pseudo-obstruction can cause hepatic portal venous gas due to bacterial overgrowth in the small bowel with translocation of gas forming bacteria through the small bowel wall.

- When hepatic portal venous gas is thought to be secondary to small bowel pseudo-obstruction, laparotomy is required to exclude small bowel gangrene. When excluded, surgical decompression of the large and small bowel and broad spectrum antibiotics is effective management. antibiotics and parenteral nutrition given. CT 6 days later showed resolution of HPVG (figure 4). His neurological condition continued to improve and normal bowel function returned. We believe that the autonomic disturbance associated with paralysis caused intestinal pseudo-obstruction. ${ }^{3}$ Bacterial overgrowth then occurred and translocation of gas forming organisms through the jejunal wall caused HPVG. Bickerstaff's encephalitis with complicating HPVG has not been previously described. ${ }^{3}$ In our case surgical decompression of the large and small bowel and broad spectrum antibiotics proved effective management.

Contributors CS and SP identified this case as worthy of publication because of the clinical importance and management issues raised by finding hepatic portal venous gas on imaging. All the authors were involved in the literature search and in writing up the case report.

Competing interests None declared.

Patient consent Obtained.

Provenance and peer review Not commissioned; externally peer reviewed.

\section{REFERENCES}

1 Abboud B, Hachem JE, Yazbeck T, et al. Hepatic portal venous gas: physiopathology, etiology, prognosis and treatment. World J Gastroenterol 2009;15:3585-90.

2 Odaka M, Yuki N, Yamada M, et al. Bickerstaff's brainstem encephalitis: clinical features of 62 cases and a subgroup associated with Guillain-Barré syndrome. Brain 2003;126:2279-90.

3 Man BL, Fu YP. Intestinal pseudo-obstruction as a presenting symptom of Guillian-Barré syndrome. BMJ Case Rep 2014;2014:pii: bcr2014205155.

Copyright 2015 BMJ Publishing Group. All rights reserved. For permission to reuse any of this content visit http://group.bmj.com/group/rights-licensing/permissions.

BMJ Case Report Fellows may re-use this article for personal use and teaching without any further permission.

Become a Fellow of BMJ Case Reports today and you can:

- Submit as many cases as you like

- Enjoy fast sympathetic peer review and rapid publication of accepted articles

- Access all the published articles

- Re-use any of the published material for personal use and teaching without further permission

For information on Institutional Fellowships contact consortiasales@bmjgroup.com

Visit casereports.bmj.com for more articles like this and to become a Fellow 